\title{
The net benefit of public expenditures on avalanche defence structures in the municipality of Davos, Switzerland
}

\author{
S. Fuchs ${ }^{1,2,{ }^{*}}$ and M. C. McAlpin ${ }^{1}$ \\ ${ }^{1}$ WSL Swiss Federal Institute for Snow and Avalanche Research SLF, Davos, Switzerland \\ ${ }^{2}$ Department of Geography, University of Innsbruck, Austria \\ *now at: alpS Centre for Natural Hazard Management, Innsbruck, Austria
}

Received: 28 July 2004 - Revised: 22 November 2004 - Accepted: 15 March 2005 - Published: 1 April 2005

Part of Special Issue "Multidisciplinary approaches in natural hazard and risk assessment"

\begin{abstract}
Avalanches pose a threat to settlements as well as industrial and recreational areas in the Alps. As a counter measure, technical mitigation measures have been implemented since the 19th century, resulting in a raise in value of formerly endangered areas. This increase in value can be considered as a benefit due to prevented damage. This paper compares the total costs and benefits of technical mitigation measures in the municipality of Davos, Switzerland as a basis for evaluating their net social benefit. The benefit of avalanche defence structures is determined using two different approaches. First, the replacement value of buildings protected by mitigation measures is quantified. Second, the number of protected persons is monetarily assessed by means of a human capital approach. The quantified benefit is compared with the present value of cumulative capital expenditures on avalanche mitigation measures. In addition, distributional effects of the public expenditures on technical mitigation measures are discussed based on the average future tax revenues within protected areas. Depending on whether benefits are calculated in terms of protected buildings or protected persons, the results show a large range of cost-benefit ratios. Critical issues of cost-benefit analyses in the context of alpine natural hazards are highlighted, including problems related to the human capital approach and the sensitivity of results to how benefits are calculated. The applicability of cost-benefit analyses for evaluating avalanche mitigation measures is discussed.
\end{abstract}

\section{Introduction}

Due to the high relief of the topography, natural hazards, such as avalanches, are part of the Swiss Alpine environment. Since the Alps have been historically used for human settlement, industry, and recreation, conflicts arise between

Correspondence to: S. Fuchs

(fuchs@alps-gmbh.com) human interests and those natural processes that have the potential to damage infrastructure and harm people. The high losses that occurred particularly in the first half of the 20th century, promoted high investments by the public sector in avalanche defence structures with less emphasis on the economic efficiency of the projects than today (Haering et al., 2002). In Switzerland, the major avalanche starting zones are equipped with avalanche protection measures, such as snow supporting structures. The total capital expenditure for those measures, from 1950 to 2000, was approximately Euro 1 billion (SLF, 2000). Those capital expenditures were distributed between the Swiss Confederation (50\% to 70\%), the cantons (in Grisons 10\%) and the communes (residue) (AfW, 1949-1996 ${ }^{1}$ ).

As a result of the increasingly limited financial resources of the public sector there is a need for an efficient and sustainable policy of public expenditures for protection against natural hazards. Consequently, the costs and benefits of avalanche defence structures will be increasingly determined to allow for a comparison of the cost-effectiveness of different measures and an evaluation of the economic efficiency of avalanche mitigation strategies. Mitigation measures are considered economically beneficial if the utility produced by them exceeds or is equal to the associated costs. In Switzerland, in the future, the various levels of government will no longer fund avalanche defence structures in fixed proportions and without consideration of their economic efficiency and only mitigation measures with net economic benefits will be funded (Bumann et al., 1999² ; Baumann et al., 2000; Haering et al., 2002).

\footnotetext{
1 AfW (Forestry Office Grisons) (1949-1996): Unterlagen zur Abrechnung kantonaler Zuschüsse für Verbauprojekte, Amt für Wald, Graubünden, Chur, unpublished.

2 Bumann, R., Burkard, A., and Wyer, M. (1999): Beurteilung des technischen Verbaus und der temporären Verbaumassnahmen. Methodischer Bericht, Beilage 4, BUWAL, Bern, unpublished.
} 
Since avalanche mitigation measures have characteristics of public goods, ${ }^{3}$ the private sector does not supply them in a sufficient quantity given the potential economic benefits to society. Therefore, the supply must take place via the public sector. In order to provide the optimal supply of avalanche protection measures, the public sector will need, among other information, evaluations of the costs and benefits of mitigation approaches. Such an evaluation can be made by comparing the costs of the supply of the good with an indirect measurement of the utility for the consumer. Literature exists on the application of cost-benefit analyses to planning for protection against natural hazards (Musgrave, 1969; Green and Penning-Rowsell, 1986; Bateman, 1992; Adams, 1993; Eade and Moran, 1996). Major trends in environmental planning in Europe can be found in Bayerisches Landesamt für Wasserwirtschaft (1981), Altwegg (1988, 1989); Löwenstein (1995); Worch (1996); and Wilhelm (1997, $1999 b)$. There are only a few approaches to cost-benefit analyses of mitigation measures. Wilhelm (1997) outlines general approaches to determine the costs and benefits of public goods. Wilhelm (1999a) presents a well-defined procedure for determining the costs and benefits of protection of roadways from avalanche risk. Wilhelm's approach was adapted by Bumann et al. (1999) ${ }^{2}$ and Baumann et al. (2000) in a broader context of Alpine natural hazards. The determination of the costs is based primarily on discounted future investments. Benefits can be far more difficult to determine, particularly when they include valuation of human life (e.g. Kahneman, 1986; Viscusi, 1993; McFadden, 1994).

During the winter of 1998/99, due to avalanches, high damage occurred in the Swiss Alps (SLF, 2000; Nöthiger et al., 2002). In early 1999, 1350 avalanches caused an estimated damage of Euro 500 million, despite investments of approximately Euro 1 billion for mitigation measures between 1950 and 2000 (without taking into account expenses for regular maintenance and accruals). This paper evaluates whether past investments in mitigation measures have produced net economic benefits. This question is discussed based on a comparison of the investments for permanent avalanche defence structures in the municipality of Davos, Grisons, Switzerland, between 1921 and 2000 and the utility gained from the resulting protection of human lives and buildings. This cost-benefit analysis uses an ex-postapproach, which is appropriate to evaluate whether or not former decisions for the implementation of measurements are efficient in a sense that benefits exceed the related costs (Frey, 1978).

A risk model allowed the calculation of benefits due to mitigation measures. Risk analyses were conducted for areas affected by avalanches in Davos. The method followed the actuarial concepts of the determination of the probable maximum loss (PML), which is the largest potentially assumable loss. A previous study shows that the risk for Davos decreased substantially between 1950 and 2000. The only exception was in the category of residential buildings, where

\footnotetext{
${ }^{3}$ For explanations regarding public goods, see the appendix A.
}

an increase in risk was detectable at medium and high recurrence intervals (Fuchs et al., 2004).

\section{Methods of evaluation}

In the first step of this analysis, the cumulative risk in 2000 for the settlement area within an avalanche run-out area was modelled for a 300-year scenario without any mitigation measures, using the numerical avalanche model AVAL-1D (e.g. Christen et al., 2002a). The avalanche calculations as well as the selection of the friction parameters $\mu$ and $\xi$ followed the guidelines given in the manual (Christen et al., 2002b). The fracture depths were obtained applying extreme value statistics by Gumbel on the possible maximum new snow height within three days in the study area. The following assumptions were made for the determination of the run-out zones:

- The release areas of the avalanches under investigation were included as a whole in the calculation, partial triggering was not assumed.

- Since in the model AVAL-1-D the parameter $\xi$ is regarded as being dependent on the friction coefficient $\mu$, the stock of wood in the transit zone was considered using the smallest possible value for the friction parameter $\xi$. A value of $400\left(\mathrm{~m} / \mathrm{s}^{2}\right)$ was stated to reproduce the real conditions very accurately (SLF, 1999), and was therefore applied during the set of calculations.

- Buildings within the accumulation area were not accounted for the protection provided by the dissipation of the force of an avalanche by upslope buildings to buildings further away from the avalanche starting zone. However, there were examples where an avalanche destroyed a building situated perpendicular to the avalanche axis (e.g. in the hamlet of Valzur, Paznaun valley, Austria, in February 1999), but there were cases where such a building was able to stop such an avalanche completely (e.g. in the village of Airolo, Ticino, Switzerland, February 1951). An important factor according for such differences in vulnerability is the structure of these buildings. Simple wooden chalets or brick buildings have only little resistance to avalanche impacts, while reinforced concrete buildings can resist medium to strong pressure intensities and retard the avalanche flux. However, investigations based on the structure of buildings require a totally different approach and a much larger measuring scale than the one used in this study. As a result, the estimates of prevented damage and estimated net benefits are higher than they would have been under consideration of the protective effect of buildings in the avalanche run-out area.

Using the 300-year scenario allows for consideration of the total area that is the basis for mitigation and land-use planning decisions by local authorities. The number and value 
of the buildings and persons affected by this scenario was calculated using a Geographic Information System (GIS).

In the second step, the cumulative risk in 2000 was calculated for a 300 -year scenario in the same areas, but under consideration of the actual mitigation measures. It was assumed that all mitigation measures are $100 \%$ efficient, even though, during the avalanche winter of 1998/99 for example, some avalanches appeared to have started within existing defence structures (SLF, 2000). The height of the error determined during modelling was considered on the basis of a $95 \%$-confidence interval by $\pm 30 \mathrm{~m}$, following the suggestions outlined in Barbolini et al. (2002). The difference between the areas affected by avalanches in the 300-year scenario without mitigation measures and in the 300-year scenario with mitigation measures can be attributed to the mitigation measures in the avalanche starting zones.

In the third step, the economic benefit was determined not for the entire damage potential of the endangered areas (probable maximum loss, PML), but using an approach presented in Wilhelm (1997) for the quantification of collective avalanche risks, which better represents empirical information on damage patterns resulting from avalanches. Wilhelm used the following assumptions:

- The design event does not cover the entire run-out area, but only a certain part of it. This assumption is based on the observation that an avalanche accumulates in a finger-shaped pattern, particularly when the accumulation area is convex (see Fig. 1). For this reason, during the calculation of benefits from mitigation measures, the affected damage potential is determined using a reduction factor based on location within either of two hazard zones in the avalanche path. The red zone is the land planning designation for the area with greater avalanche exposure and the blue zone is the area with less avalanche exposure ${ }^{4}$. This reduction factor is 0.8 inside the red zone and 0.5 inside the blue zone for a 300-year design event (Wilhelm, 1997; Bumann et al., $\left.1999^{2}\right)$.

- The average susceptibility of buildings to be damaged is 1.0 inside the red zone and 0.3 inside the blue zone for a 300-year design event (Wilhelm, 1997; Bumann et al., $1999^{2}$ ).

The assumption was that the avalanche events occur at the beginning of the time period and then take the total cost over the remainder of the time period. As a result, the calculation of net benefit provided the upper bound for the total benefit. If the assumption would have been that the events occurred at the end of the time period, the discounted present value of the total benefit would be smaller and the ratio of cost to benefit greater.

\footnotetext{
${ }^{4}$ For explanations regarding red and blue avalanche zones and their importance for land-use planning in Switzerland, see the appendix B.
}

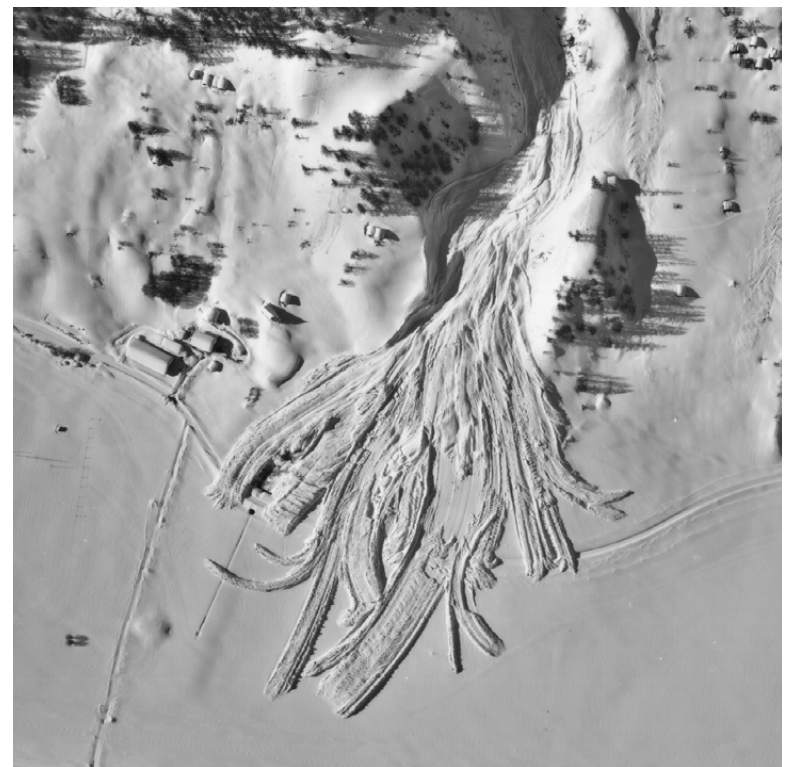

Fig. 1. Finger-shaped avalanche accumulation during the winter 1998/99 westwards of the municipality of Ulrichen, Valais, Switzerland. Reproduced with permission of the Swiss Federal Office of Topography, Center for the Coordination of Aerial Photography (CCAP).

\subsection{Determination of costs}

The cost of mitigation measures is evaluated in terms of the present value of the previous investment so that the opportunity costs can be compared to the utility that would have resulted from an alternative appropriation of the resources. The capital expenditures for avalanche mitigation measures were made available by the forestry office in Grisons (AfW, 1949$1996^{1}$ ). Their present value was calculated using Eq. (1), based on the real interest rate, which takes into account inflation and therefore allows comparison of expenditures in different years. $K_{n}$ is the present value of the total capital at the expiration of the validity in Euro, $p$ is the real interest rate in percent, $s$ is the interest period, $n$ the term, and $K_{0}$ the opening capital in Euro. The real interest rate $i_{\text {real }}$ was calculated on the basis of the nominal interest rate $i_{n o m}$ and the inflation $J$, using Eq. (2). The nominal interest rate was derived from the average rate of interest of the confederate bonds, as provided by the Swiss National Bank. The rate of inflation was provided by the Swiss Federal Statistical Office.

$$
\begin{aligned}
& K_{n}=\left(1+\frac{p \cdot s}{100}\right)^{n} \cdot K_{0} \\
& i_{\text {real }}=\left(\frac{1+i_{\text {nom }}}{1+J}\right)-1
\end{aligned}
$$

\subsection{Determination of utility}

The utility related to avalanche mitigation measures can be determined in two different ways, both of which are described below and used in the cost-benefit analyses. 
- The utility can be defined in the sense of prevented damage to buildings, the so-called method of loss expenses. Because market processes (here for real estate within avalanche-endangered areas) are able to reflect the real costs, market values, from an economic point of view, are particularly suitable for the determination of possible damage. There are essentially two arguments against the use of market values: First, the market value for buildings is subject to variations. If, at the time of investigation, the market demand for the buildings is high, their current value may be above the replacement value. If, for example, due to an avalanche event, there is no demand on the market for those buildings, their value could be zero. The second argument follows the first: it is the philosophy of the mandatory building insurer to underwrite the risk due to the replacement value to be able to compensate for an eventual total loss and to enable a replacement of the damaged building at any time. Thus, the replacement value is used as an approximation within this study, neglecting any risk-dependent change in the demand of buildings on the market. Following this method, data concerning the number of potentially affected buildings and their insured replacement value was collected, as provided by the mandatory building insurance (GVA building insurance company of Grisons). Since these values have been adjusted to take into account for inflation, the insured sums can be directly compared to the respective year of construction.

- In a second set of calculations, the utility is evaluated in terms of the number of lives protected. The number of persons in the endangered areas was determined on the basis of the number of domiciles. Statistics indicated 2.4 residents per unit in the year 2000 (BfS, 2002). Subsequently, an assessment of the value of the number of persons was done, using a human capital approach. This procedure can be traced back to approaches in the insurance business, where financial compensation is paid to the immediate family upon the premature demise of the policy holder. The value of human life was calculated as follows: In Switzerland, the annual gross earned income per working person amounted to Euro 45240 for the year 2000 (BfS, 2002). The average age of the population amounts to 39.4 years for men and 42.8 years for women (BfS, 2002). Thus, until an average retirement age of 65 years, a remaining average expectancy of working life of 25.6 years for men and 22.2 years for women results, resulting in a mean of 23.9 years which has been rounded up to 24 years for this study. Equation (3) was applied to calculate the annuity value $R_{0}$ from the payment $r$, the factor $q$, and the term $n$. The factor $q$ is derived summing up the rate of interest $i$ with 1 . The rate of interest was calculated with 0.0132 , as provided by the Swiss National Bank for the average rate of interest of the confederate bonds. Applying Eq. (3) for the annuity value with the interest paid at the end of the period, an average of Euro 925405 re- sults for the annuity value corresponding to the income of an average person during the remaining working life. Thus, following the human capital approach, the average value of one human life lost during an avalanche event is approximately Euro 925000.

$R_{0}=r \cdot q^{-n} \cdot \frac{q^{n}-1}{q-1}$

This analysis also examines distributional implications of the investments in avalanche defence structure by comparing the total future revenue from taxes of persons living in endangered areas with the cost of the measures. This approach assumes that the residents of endangered areas could not live there without mitigation measures and consequently would not be liable for income tax. In Switzerland, the average level of income tax to be paid is $9.7 \%$ of the gross income (Bundesrat, 1998). Thus, the total expected tax revenue for the community due to the construction of avalanche defence structures can be approximated by Euro 925000 times 0.097, resulting in Euro 89725 per residential person, as lost duties due to a premature demise of the person, under the assumption of a constant taxation in Switzerland. Due to the distribution of income tax revenues in Switzerland, about 10\% of this sum is used annually by the Confederation, while the residue is split between the tax payer's residential canton and municipality.

\section{Results of evaluation}

\subsection{Investments in avalanche defence structures}

The municipality of Davos (districts "Platz" and "Dorf") is affected by four avalanche paths in the following areas: Schiahorn, Dorfberg, Dorfbach and Alberti (see Fig. 2). The related expenditures for the protection of the settlement areas are considerable: The avalanche defence structures in the Schiahorn area alone comprise $3315 \mathrm{~m}$ ' of stonework that was installed mainly during the first period of construction between 1921 and 1925 (Henne, 1925), 2240 m' of mixed terraces, 4262 m' of permanent snow rakes and 1125 m' of wooden snow rakes, for a total of $10942 \mathrm{~m}$ ' of defence structures (AfW, 1949-1996 ${ }^{1}$ ). The costs for those defence structures amount to k Euro 25648 (adjusted to inflation and compounded interest). The costs for the Dorfberg area amount to kEuro 11 034, those for the Dorfbach area to k Euro 698 (avalanche-retarding mounds and a dam). In the Alberti area, no avalanche defence structures were installed, since the existing torrent defence works are regarded to be effective against avalanches due to an increased roughness of the surface (Spinatsch, 2003, pers. comm.). Thus, the costs for the torrent defence works were neglected in this study, since they are no avalanche defence works in a narrower sense.

The costs of construction of the avalanche defence structures in the whole study area amount to kEuro 37381 for the accounting period 1921-2000, adjusted to inflation and accumulated according to Eq. (1). $71 \%$ of this value 
Table 1. Investments for avalanche defence structures in the municipality of Davos, Switzerland, taking into account the accounting periods. The figures were adjusted to inflation and unaccrued interest was added, the price basis is the year 2000. In the right column, the total costs, including maintenance costs, are presented.

\begin{tabular}{lrrrr}
\hline $\begin{array}{l}\text { Accounting } \\
\text { period (year) }\end{array}$ & $\begin{array}{r}\text { Investments } \\
\text { (Euro) }\end{array}$ & $\begin{array}{r}\text { Portion of total } \\
\text { investments (\%) }\end{array}$ & $\begin{array}{r}\text { Maintenance } \\
(1 \% \text { of investments/year) }\end{array}$ & $\begin{array}{r}\text { Total costs } \\
(\text { Euro })\end{array}$ \\
\hline Until 1949 & 26588501 & 71.12 & 18045261 & 44633764 \\
$1950-1951$ & 329287 & 0.88 & 161351 & 490638 \\
$1952-1953$ & 39959 & 0.19 & 32881 & 102840 \\
$1954-1974$ & 5835913 & 15.61 & 1517338 & 7353252 \\
1975 & 1206792 & 3.24 & 301698 & 1508490 \\
$1976-1984$ & 916986 & 2.45 & 146718 & 1063705 \\
1985 & 902170 & 2.41 & 135325 & 1037495 \\
$1986-1989$ & 409848 & 1.10 & 45083 & 454931 \\
$1990-1996$ & 1121222 & 3.00 & 44849 & 1166071 \\
\hline$\sum$ & 37380678 & 100.0 & 20430504 & 57811184 \\
\hline
\end{tabular}

(k Euro 26 589) was spent in the period from 1921-1949 (see Table 1). A relatively high proportion of the investments was done in the 1970s (a total of k Euro 7,043 which is approximately $19 \%$ of the total investments) due to increased public pressure for avalanche protection, which was driven by an increase in the number of buildings in the 1960s and early 1970 s and the relatively high damage in Davos during the winter of 1967/68 (Fuchs and Bründl, 2005).

When maintenance costs are included, which were determined to be $1 \%$ of the total investment costs per year because it was assumed that snow supporting structures have an average life-cycle of 100 years, the total cost of technical mitigation measures in the four areas from 1921-2000 amounts to k Euro 57811 (see Table 1). 77\% of the total amount account for the accounting period until $1949,15 \%$ for the accounting period in the 1970 s and $8 \%$ for the remaining periods.

\subsection{Endangered buildings}

In Table 2, the number and the value of the endangered buildings is presented for the year 2000. In the columns on the left, data resulting from the calculated 300-year scenario without mitigation measures is presented. The columns on the right show data resulting from the 300-year scenario with mitigation measures. Without the construction of mitigation measures, 458 buildings with an insured value of k Euro 714672 would be endangered in the avalanche accumulation areas. Taking into account the mitigation measures, 125 buildings with an insured value of k Euro 121756 remain vulnerable to damage. Furthermore, the buildings were separated into six categories, which are residential buildings, commercial buildings, hotels and guest houses, agricultural buildings, special-risk buildings, such as hospitals or buildings of the public administration, and other buildings. It becomes apparent that in both scenarios the category of residential buildings show the highest exposure to loss both for the number

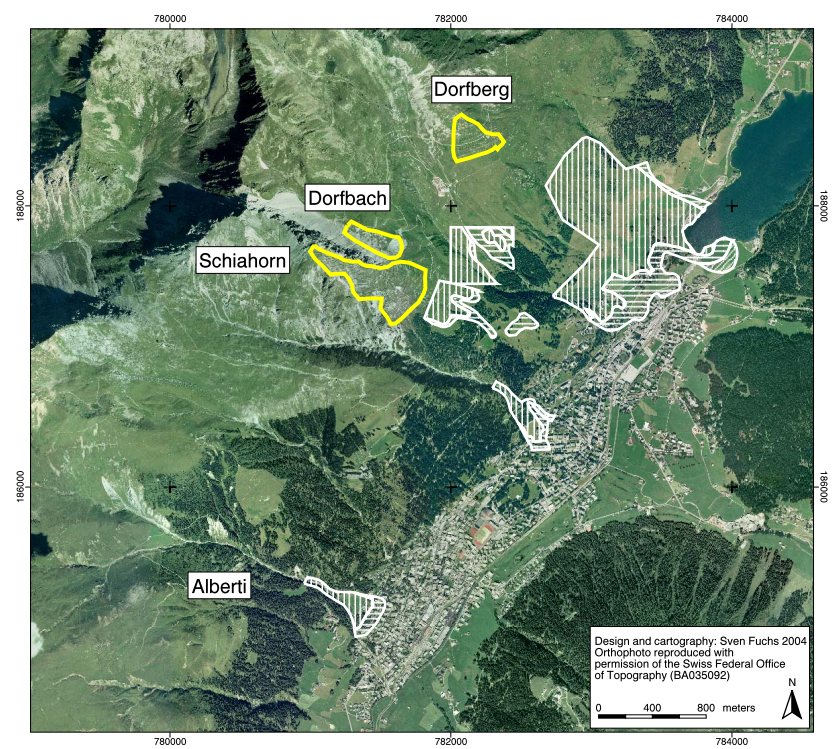

Fig. 2. Study area within the municipality of Davos, Switzerland. The solid yellow lines indicate the avalanche mitigation measures at Dorfberg, Dorfbach and Schiahorn. The hatched raster shows the avalanche hazard zones. Vertical hatching represents the red hazard zone, horizontal hatching the blue hazard zone, and oblique hatching the yellow hazard zone, for explanations, see the appendix B. Reproduced with permission of the Swiss Federal Office of Topography, Center for the Coordination of Aerial Photography (CCAP).

and for the insured value, and consequently for the number of endangered persons (see Sect. 3.3).

Applying the method of loss expenses, the results quantified in the scenarios described above were subtracted from each other, resulting in an upper limit of utility under consideration of an error bar of $\pm 30 \mathrm{~m}$ due to modelling uncertainties (see Table 3 and Fig. 3). This upper limit represents 
Table 2. Number $(\mathrm{N})$ and value of buildings and number of residential population in the buildings affected by the scenarios under investigation, calculated on basis of the situation in the year 2000. In the left section, results from the scenario without mitigation measures are presented. In the right section, results from the scenario under consideration of mitigation measures are presented. The difference between those two scenarios is considered as net benefit due to mitigation measures. $\mathrm{N}$ is the number of buildings affected by the scenarios.

\begin{tabular}{lrrrrrr}
\hline & $\begin{array}{l}\text { 300-year } \\
\text { measures }\end{array}$ & scenario & without & mitigation & \multicolumn{2}{c}{$\begin{array}{l}\text { 300-year scenario under consideration of } \\
\text { mitigation measures }\end{array}$} \\
\hline & $\mathrm{N}$ & $\begin{array}{c}\text { Value } \\
\text { (k Euro) }\end{array}$ & $\begin{array}{c}\text { Residential } \\
\text { population* }\end{array}$ & $\mathrm{N}$ & $\begin{array}{c}\text { Value } \\
\text { (k Euro) }\end{array}$ & $\begin{array}{r}\text { Residential } \\
\text { population* }\end{array}$ \\
\hline Residential buildings & 252 & 293982 & 4442 & 93 & 87856 & 1116 \\
Commercial buildings & 47 & 64158 & 309 & 1 & 5902 & 2 \\
Hotels/guest houses & 43 & 147422 & 377 & 4 & 5633 & 12 \\
Agricultural buildings & 16 & 4589 & 0 & 7 & 3287 & 0 \\
Special-risk buildings & 23 & 80663 & 93 & 4 & 3450 & 7 \\
Other buildings & 77 & 123858 & 0 & 16 & 15628 & 0 \\
\hline$\sum$ & 458 & 714672 & 5221 & 125 & 121756 & 1137 \\
\hline
\end{tabular}

* Principal and secondary residences

Table 3. Benefit from mitigation measures, based on the calculated scenarios. The bias due to the consideration of a modelling error of $\pm 30 \mathrm{~m}$, on the basis of a 95\%-confidence interval, is based on the ideas outlined in Barbolini et al. (2002). N is the number of buildings protected by the mitigation measures.

\begin{tabular}{|c|c|c|c|c|c|c|c|c|c|}
\hline & \multicolumn{2}{|c|}{ Scenario "-30 m" } & & \multicolumn{2}{|c|}{ Accurate scenario } & \multicolumn{4}{|c|}{ Scenario “+30 m" } \\
\hline & $\mathrm{N}$ & $\begin{array}{r}\text { Value } \\
\text { (k Euro) }\end{array}$ & $\begin{array}{r}\text { Residential } \\
\text { population }\end{array}$ & $\mathrm{N}$ & $\begin{array}{r}\text { Value } \\
(\mathrm{k} \text { Euro) }\end{array}$ & $\begin{array}{l}\text { Residential } \\
\text { population }\end{array}$ & $\mathrm{N}$ & $\begin{array}{r}\text { Value } \\
\text { (k Euro) }\end{array}$ & $\begin{array}{l}\text { Residential } \\
\text { population }\end{array}$ \\
\hline Residential buildings & 187 & 247268 & 3862 & 159 & 206126 & 3326 & 122 & 173677 & 2597 \\
\hline Commercial buildings & 50 & 64929 & 310 & 46 & 58256 & 307 & 45 & 58062 & 297 \\
\hline Hotels/guest houses & 39 & 141789 & 365 & 39 & 141789 & 365 & 38 & 138539 & 307 \\
\hline Agricultural buildings & 16 & 5915 & 0 & 9 & 1302 & 0 & 8 & 350 & 0 \\
\hline Other buildings & 69 & 113,669 & 0 & 61 & 108,230 & 0 & 52 & 102,903 & 0 \\
\hline$\sum$ & 382 & 653594 & 4626 & 333 & 592916 & 4084 & 283 & 543440 & 3285 \\
\hline
\end{tabular}

the worst-case scenario, as empirical evidence suggests that the risk model overestimates damage potential due to uncertainties in the accumulation behaviour of avalanches. Altogether, due to the construction of avalanche defence structures in Davos, $333( \pm 15 \%)$ buildings with an insured value of kEuro 592916 ( \pm approximately 10\%) were protected. Around half of them (159 with an insured replacement value of kEuro 206126) are within the category of residential buildings. In the category of residential buildings, the scattering of results is the highest of all the categories, $\pm 20 \%$ in number and $\pm 18 \%$ in value. In the category of hotels and guest houses, 39 buildings with an insured value of k Euro 141789 were protected ( $-2 \%$ under consideration of an expansion of the avalanche accumulation areas by $30 \mathrm{~m}$ ). The third-largest class in value is the category of other buildings, such as annexes and garages. 61 buildings ( \pm approximately $15 \%)$ with an insured value of k Euro $108230( \pm 5 \%)$ are included in this category. While these buildings have relatively low values due to inexpensive construction, they can contain a high damage potential for movable property (Keiler et al., 2005). The cost-benefit ratio of this upper limit is 1:16.6 (1:17.5-1:14.7 under consideration of the error bars) for all the study areas combined. Taking into account the expenditures for maintenance costs results in a cost-benefit ratio of 1:9.7, without the consideration of error bars.

For individual areas in this study, the cost-benefit ratios vary, which can be attributed partly to the level of mitigation on the one hand and the amount and type of building development on the other hand.

Within the study area beneath the Dorfberg, 81 buildings with an insured replacement value of kEuro 147342 were protected. The related investments, under consideration of inflation and unaccrued interest, amount to a total present value of k Euro 11034 . Taking into account the expenditures for maintenance, a total cost of kEuro 17206 results. The upper limit of the cost-benefit ratio, considered in terms of probable maximum loss (PML), is 1:13.4 for the investment costs alone and 1:8.6 considering maintenance expenditures. 
Following the suggestions of Wilhelm (1997) outlined in section 2, the cost-benefit ratio increases due to decrease of the affected damage potential by $85 \%$. The utility is reduced to 12 buildings with an insured value of k Euro 22101 . Thus, the cost-benefit ratio is $1: 2$ without and 1:1.3 with expenditures for maintenance. The value of the protected buildings exceeds the costs of the mitigation measures by $30 \%$.

Within the study area beneath the Schiahorn, 82 buildings with an insured replacement value of kEuro 159143 were protected. The related investments, under consideration of inflation and unaccrued interest, amount to a total present value of kEuro 25648 . Taking into account the expenditures for maintenance, a total cost of k Euro 40207 results. The upper limit of the cost-benefit ratio, considered in terms of probable maximum loss (PML), is 1:6 for the investment costs alone and 1:4 considering maintenance expenditures. Following the suggestions in Wilhelm (1997), the utility is reduced to 12 buildings with an insured value of kEuro 23872 . Thus, the cost-benefit ratio is 1:0.9 without and 1:0.6 under consideration of expenditures for maintenance. These results do not necessarily indicate that the avalanche mitigation measures at Schiahorn are inefficient. They are the result of the method used within this section, because the calculations are only based on the insured replacement values and any additional effects, such as a valuation of human lives, have not been taken into consideration. Furthermore, possible sources of uncertainty resulting from the economic methods used, such as differences between market prices for endangered buildings and replacement values for those buildings, have not been taken into account.

\subsection{Residential population}

The number of affected persons (residential population) is presented in Table 2, separated into the building categories mentioned above. In the left column, results from the scenario without mitigation measures are presented. In the right column, results from the scenario with mitigation measures are presented. In the former scenario, 5221 persons are affected, in the latter scenario only 1137, which corresponds to a reduction of $78 \%$. Consequently, most of the persons can be located in residential buildings, 4442 persons without mitigation measures and 1116 persons with mitigation measures, which is $75 \%$ reduction of endangered persons.

The utility from the realisation of mitigation measures is presented in Table 3. 4084 persons are protected by mitigation measures, whereas the range is between $4626(+13 \%)$ and $3285(-20 \%)$. Residential buildings account for the highest proportion of protected people, which amounts to 3326 persons with a range between $3862(+14 \%)$ and 2597 $(-22 \%)$.

The utility resulting from mitigation measures can be expressed in monetary terms calculated from the number of endangered human lives, assessed by means of the human capital approach. Applying this approach, only fatalities were assessed, but not expenditures for injured persons or the related
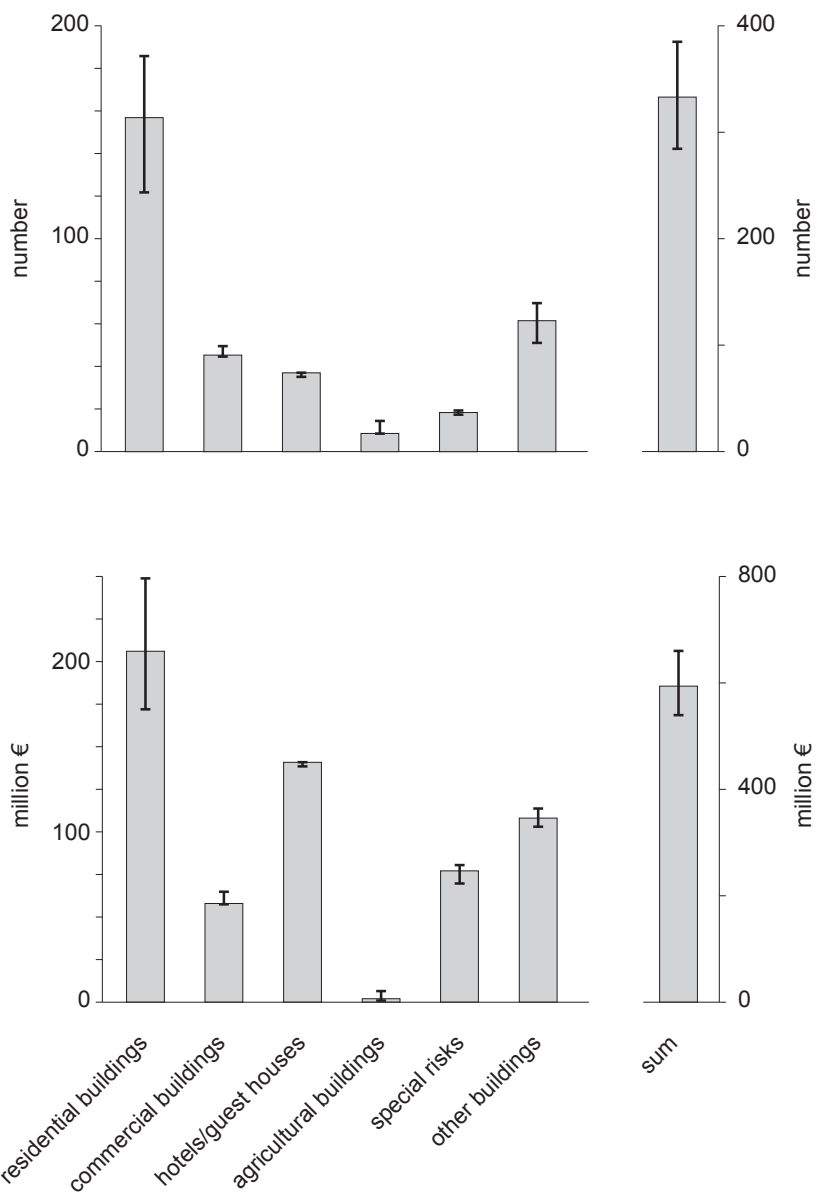

benefit due to mitigation measures

I error bars due to modelling

Fig. 3. Benefit due to mitigation measures in the municipality of Davos. In numbers, the highest net benefit is within the category of residential buildings, followed by the category of other buildings and commercial buildings. In value, the highest net benefit is within the category of residential buildings, followed by the category of hotels and guest houses, and the category of other buildings.

secondary effects, like losses of earnings due to a trauma or the like.

Analysis of data from the database of destructive avalanches of the Swiss Federal Institute for Snow and Avalanche Research (Laternser et al., 1998) has shown an average fatality rate of $46 \%$ for persons buried in buildings due to an avalanche event. Thus, the total number of endangered persons is reduced by this fatality factor, and a total of 1879 persons had to be taken into account for the calculation (range between 2128 and 1511 persons). Applying the human capital approach to these numbers, the benefit due to mitigation measures in Davos is k Euro 1738075 (range between kEuro 1968400 and kEuro 1397675 ). Thus, the cost-benefit ratio under consideration of the investments and the maintenance costs is $1: 30(1: 34-1: 24)$. 
The cost-benefit ratio varies for the individual avalanche paths, as exemplarily shown for the area below the Dorfberg and the Schiahorn area.

Due to the construction of avalanche defence structures, 682 persons were protected beneath the Dorfberg. Applying the fatality factor, the utility from mitigation measures is 314 persons, which have a value of kEuro 290450 . Thus, the cost-benefit ratio is 1:17. Considering the method suggested by Wilhelm (1997), the utility beneath the Dorfberg is reduced to 47 persons or kEuro 43400 , which corresponds to a cost-benefit ratio of $1: 2.5$ (with consideration of the investments and the maintenance cost).

Due to the construction of avalanche defence structures, 1054 persons were protected beneath the Schiahorn. Applying the fatality factor, mitigation measures protected 485 persons beneath Schiahorn, which is k Euro 448625 . Thus, the cost-benefit ratio is 1:11. Considering the method suggested by Wilhelm (1997), the utility beneath the Schiahorn is reduced to 73 persons or kEuro 67525 , which corresponds to a cost-benefit ratio of $1: 1.7$ with consideration of the investments and maintenance costs.

\subsection{Tax revenue}

Avalanche defence structures are largely investments by the public sector. Thus, the cost for the public sector can be compared with the expected future tax revenue within the protected areas in order to examine distributional effects of expenditures on mitigation. The ratios of costs and revenues provide information on how costs and benefits of avalanche defence measures are distributed between tax-payers in general and those people who receive the benefits because they live in the endangered areas.

The 4084 persons who live in the endangered areas in the four avalanche paths included in this study have an average tax liability of k Euro 366437 in their remaining average working time. Due to the range of the avalanche accumulation areas, this value scatters between k Euro 415068 and k Euro 294747 . Using these values of expected tax revenue, the cost-revenue ratio is $1: 6.3(1: 7.2-1: 5)$. If the ratio is calculated merely for the statistically prevented fatalities, the utility is reduced to 1879 persons owing k Euro $168593 \mathrm{fu}$ ture tax revenue, the related cost-revenue ratio is reduced to 1:2.9.

Following the method suggested by Wilhelm (1997), the potential revenue from the area beneath the Dorfberg is reduced to 47 persons or k Euro 4210 future tax revenue, which corresponds to a cost-revenue ratio of 1:0.07 (considering the investments and the maintenance costs). The utility beneath the Schiahorn is reduced to 73 persons or kEuro $6550 \mathrm{fu}$ ture tax revenue, which corresponds to a cost-revenue ratio of 1:0.11.

Mitigation measures are financed by three levels of government in Switzerland. The highest percentage is provided by the Swiss Confederation, followed by the shares of the canton of Grisons and the municipality of Davos. It is assumed that the municipality of Davos benefits from the fi- nancing of mitigation measures, directly from the possibility of expanding the land open to development and indirectly from the feeling of safety among the tourists and the residential population. Thus, the question of redistribution mainly concerns the shares of the Confederation and the canton as compared with associated revenue from income taxes on inhabitants within avalanche paths. To demonstrate distributional effects of expenditures on avalanche mitigation, this analysis focuses on the Confederation level. The Confederation share of income tax revenues is $10 \%$ of the total revenue, as outlined in Sect. 2. The total Confederation contributions to the avalanche protection measures from the municipality of Davos between 1921 and 2000 (districts "Dorf" and "Platz") amount to k Euro 32710 (considering inflation and unaccrued interest). When the contributions of the municipality of Davos and the canton of Grisons are subtracted from the total investment costs, the cost-revenue ratio for investments by the Swiss Confederation becomes 1:0.5. As a result, under the assumption that the whole future tax revenue would be used for the Confederation's expenditures for mitigation measures, twice as many people subsidise the Confederation's expenditures on mitigation measures than profit from them.

For the Dorfberg area, the Confederation's expenditures amount to k Euro 9709 (considering inflation and unaccrued interest). Following the method outlined in Wilhelm (1997), the Confederation share of the potential revenues from the Dorfberg area is reduced to kEuro 421 . Thus, the costrevenue ratio is 1:0.04. As a result, approximately twenty times as many people subsidise the expenditures in mitigation measures by the Confederation than profit from them.

For the Schiahorn area, the expenditures spent by the Confederation amount to kEuro 22189 (considering inflation and unaccrued interest). Following Wilhelm (1997), the Confederation share of the potential revenues from the Schiahorn area is reduced to $\mathrm{k}$ Euro 655 . Thus, the cost-revenue ratio is 1:0.03. Therefore, approximately thirty times as many people subsidise the expenditures in mitigation measures by the Confederation than profit from them.

\subsection{Conclusion}

In the above sections, cost-benefit ratios for the technical avalanche protection measures in the center of the municipality of Davos, Switzerland were discussed from an ex-post perspective. Depending on the method for the quantification of the related utility, a wide range of ratios of probable maximum loss (PML) was determined: 1:30 for endangered persons and 1:10 for endangered buildings. Applying the suggestions outlined in Wilhelm (1997), the cost-benefit ratios in the Dorfberg area are 1:2.5 for endangered persons and 1:1.3 for endangered buildings. In the Schiahorn area, the ratios are 1:1.7 for endangered persons and 1:0.6 for endangered buildings. In terms of future tax revenue, the cost-revenue ratio at the municipal level is $1: 6.3$ and 1:2.9 considering statistically prevented fatalities. Applying the method outlined 
in Wilhelm (1997) the cost-revenue ratio is reduced to 1:0.07 in the Dorfberg area and 1:0.11 in the Schiahorn area.

With respect to the protection of endangered persons, the prevention projects have net economic benefits in each of the four endangered areas. With respect to endangered buildings, the prevention projects have net benefits on a municipal level and for each of the endangered areas except for that beneath the Schiahorn, where the capital investments exceed the insured values of the protected buildings.

With respect to spending by the Confederation on avalanche defence measures, on a municipal level, the costs of the prevention measures are two times higher than the expected future total tax revenue. The costs of protecting the Dorfberg area and the Schiahorn area are twenty times and thirty times higher than the expected future revenues. Thus, mitigation measures in Davos can be considered as subsidies for habitation in endangered areas. At the same time, however, governmental expenditures for mitigation measures for endangered areas may also result in lower demand, and consequently, lower prices for real estate outside endangered areas.

The assumptions made in this study are conservative, due to the separate assessment of benefits resulting from prevented damage to buildings and from prevented human lives. A summary valuation of benefits would decrease the ratios of costs to benefits. In terms of probable maximum loss (PML), the ratio of costs to benefits would be 1:40. Applying the suggestions outlined in Wilhelm (1997), the ratios would be 1:3.8 for the Dorfberg area and 1:2.3 for the Schiahorn area.

However, only direct costs were taken into account, not the wider social and environmental effects, such as a possibly negative image caused by an impairment of the natural scenery due to snow rakes in avalanche starting zones. Indirect benefits, such as the non-monetary value of a person and the value of a feeling of public safety, were not included. Inclusion of indirect costs would have raised the ratios of costs to benefits, inclusion of indirect benefits would have reduced these ratios.

\section{Discussion}

Evaluations of the net benefits of natural hazards protection measures will vary as the local context changes. The relatively high property values in Davos and relatively high incomes of persons in Switzerland produced net benefits that are higher than they would be in other areas or countries with lower property values and incomes.

This analysis indicates that the avalanche protection measures have provided net economic benefits on a municipal level when benefits are valued either in terms of protection of human life or in terms of buildings. Following the suggestions outlined in Wilhelm (1997), the avalanche protection measures do not have positive net benefits in terms of protected buildings for the Dorfberg and Schiahorn areas. This suggests that, if only the direct effects included in this analysis are considered and, furthermore, if only endangered

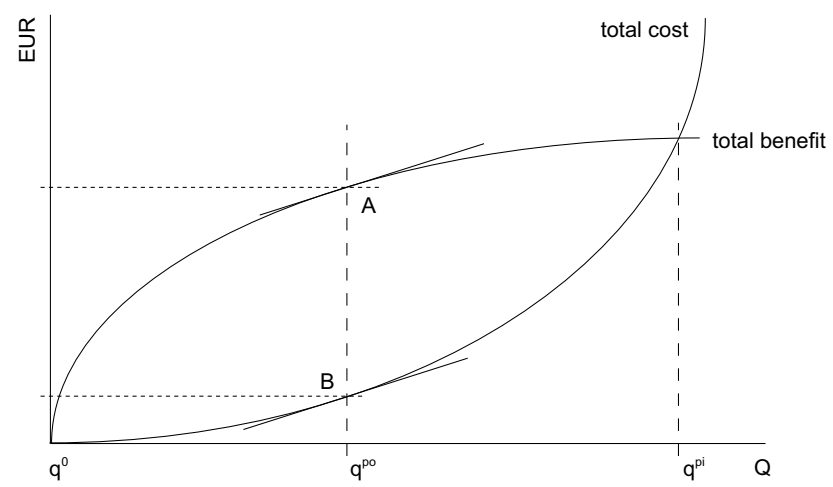

Fig. 4. Schematic illustration of total cost and corresponding total benefit due to the implementation of avalanche mitigation measures in the municipality of Davos. At the level of mitigation $\mathrm{q}^{0}$, the marginal benefit of additional mitigation is higher than the cost. Thus, further investments produce net benefits. At $\mathrm{q}^{p o}$, the slope of total benefit (A) and the slope of total cost (B) are equal, the marginal benefit and marginal cost per unit of mitigation are equal, and the level of mitigation is optimal. As the level of mitigation increases beyond $\mathrm{q}^{p o}$ up to $\mathrm{q}^{p i}$, where the total costs are the same as the total benefits, the total supply of avalanche mitigation still provides positive net benefits but is greater than optimal because the marginal cost of each additional unit of mitigation exceeds the corresponding marginal benefit. Beyond $\mathrm{q}^{p i}$, the total supply of mitigation produces negative net benefits.

buildings are taken into account, a lower supply of avalanche protection in these areas could have produced net benefits.

For future decisions about the optimal supply of avalanche protection measures, evaluations of the marginal costs and benefits of avalanche protection measures are needed. Figure 4 shows a theoretical model of total cost and total benefits for avalanche defence structures. The laws of diminishing marginal utility and increasing marginal cost suggest that the supply of each additional unit of "avalanche protection" produces an increasingly smaller benefit than the previous unit, while, the supply of each additional unit has an increasingly greater cost. At $\mathrm{q}^{p o}$, the slope of total costs and total benefits is equal and the marginal cost-benefit ratio is $1: 1$. At this point, the allocation of resources is economically efficient. Thus, a comparison of marginal costs and benefits would indicate the economically efficient supply of avalanche protection measures. A marginal cost-benefit analysis of possible avalanche protection measures in each of the endangered areas in the municipality of Davos may suggest potential gains in economic efficiency from additional investments in some areas and lower levels of investment in others.

The comparison of expected tax revenues with costs of avalanche protection for the Confederation indicates that the inhabitants of the endangered areas are subsidised by the larger population. The cost for mitigation measures are born by a larger community than the community of the beneficiaries. Normative appraisals of the distributional effects of the avalanche defence measures belong in the arena of public policy, as all people liable for taxation may or may not value 
the subsidisation of protection against avalanches for people who live in endangered areas.

Although there may be potential gains in economic efficiency from changing the supply of avalanche protection in some areas in the municipality of Davos, the decision to supply more or less avalanche protection is a political one. Cost-benefit analysis can only inform, rather than answer, the question of how much risk protection the public sector should provide. The choice of how much to invest in mitigation measures depends on the political determination of a standard of protection. The standard may be set in terms of economic efficiency, the level of expenditures, as a target for the maximum number of lives lost, or in some other way. In addition to the need to incorporate cost-benefit analyses into a broader context of political decision-making, there are still unresolved issues involved in using cost-benefit analyses as information for decisions about the level of protection against natural hazards in Switzerland. First, most cost-benefit analyses assume that effects should be evaluated with respect to the preferences of individuals (Nash et al., 1975). However, since some people benefit more directly from mitigation measures than others, the preferences for the measures may be different among the group of people who live in endangered areas and among those who live outside those areas. Therefore, cost-benefit analyses are affected by whose preferences are used to determine the benefits of mitigation measures. Second, while the utility from protecting property from natural hazards can be determined with relative ease and minimal debate, as the property values are already expressed in monetary terms, the valuation of protecting people from natural hazards requires placing a monetary value on each human life in the absence of objective rules for doing so (e.g. Adams, 1974; Viscusi, 1993; Pearce, 1998). The human capital approach used in this cost-benefit analysis raises ethical issues, as it values old people less than young or middle-aged people. Third, problems may arise in the aggregation of material assets and non-material assets, such as human life.

Despite its limitations, economic analysis can contribute by providing information for the political choice of a standard of protection against natural hazards and on how to achieve the politically determined standard. Cost-benefit analysis is simplified considerably when different alternatives attaining the same utility are evaluated against each other. This approach would apply in the situation where a level of risk acceptance has been set by the relevant community and the question is how to most effectively meet this standard. In order to determine the most competitive alternative, only relative comparisons of cost-effectiveness are necessary, which avoids the problems associated with valuing human lives. Cost-benefit analysis offers a tool for policy decisions because it allows for the comparison of monetary and non-monetary factors. The comparison of economic costs and benefits is one consideration that may facilitate decision-making about protection against natural hazards.

\section{Appendix A}

Avalanche protection measures are considered to be public goods. In a narrower sense, they represent local public goods, because they benefit primarily the residential population. Avalanche protection measures have the following characteristics of public goods:

For an inhabitant ofa settlement, the quality of avalanche protection does not change by the utilisation of the same good by another inhabitant. The marginal costs of the utilisation of the avalanche protection measures by an additional user are zero and, as a consequence, there is no market price for this good. Consumption of the utility from this public good is not necessarily fully valued by the users and, as a result, the private sector fails to provide this good at a sufficient level for economic efficiency. In some cases, due to the scarcity of protected areas for development within avalanche paths, potential users could be excluded from the utilisation. This scarcity would make avalanche protection measures common (pool) resources, for which use by some decreases the potential utility to others (Mankiw, 2001). Related to the scarcity of development areas, and the possibility of an exclusion of potential users via market prices for scarce plots, avalanche protection measures can also be described as club goods, which is a special form of public goods.

Avalanche protection measures are also characterised by a non-excludability of the utilisation of the good. No user can exclude, independently of the individual willingness to pay, another user from utilisation. Non-excludability creates incentives for free riding because people can attain the utility of a good without paying for it. Free riding is a source of market failure because, since people pay for less than the efficient quantity of a good, the market produces less than the efficient quantity of the good.

In the theory of public goods it is assumed that individuals are aware of their preferences. However, consumers might not always be aware of their preferences for avalanche protection measures, which can be partly attributed to free supply and passive consumption. The preferences for such preventive supply of a subsidy are frequently not only unknown, but also unstable and unequally distributed (Brümmerhoff, 1996).

\section{Appendix B}

It is the responsibility of the Swiss cantons to protect people's life and property from natural hazards such as avalanches, landslides, erosion and rockfalls in accordance with the Federal Law of 22nd June 1979 relating to land-use planning. Further implementation instructions result from the appropriate articles in the Federal Law of 4th October 1991 relating to forests and the Federal Law of 21st June 1991 relating to hydraulic engineering. According to these laws and associated decrees, the appropriate specialised offices of the federal authorities have to compile guidelines to encourage the consideration of natural hazards in land-use planning. 
The principles for general planning issues are published in Heinimann et al. (1998), whereas the "Guidelines for the Consideration of the Avalanche Danger in Land-Use Planning Activities" have been approved in 1984 (BFF and SLF, 1984). These guidelines describe the two main instruments for the inclusion of avalanche danger in land-use planning, namely avalanche incident documentation and the avalanche hazard map. This hazard map divides an examined area into different subsections with different danger levels according to the severity and the likelihood of potential avalanche hazards (BFF and SLF, 1984).

Red indicates areas where pressure from avalanches with recurrence intervals $\mathrm{T}$ between 30 and 300 years exceeds a lower limit that ranges from $3 \mathrm{kPa}$ for $\mathrm{T}=30$ years to $30 \mathrm{kPa}$ at $\mathrm{T}=300$ years. The entire area affected by (dense flow) avalanches with $\mathrm{T}<30$ years is also marked in red.

Blue indicates areas where pressure from avalanches with recurrence intervals $\mathrm{T}$ between 30 and 300 years falls below $30 \mathrm{kPa}$. Areas affected by powder avalanches with reoccurrence intervals $\mathrm{T}<30$ years and a pressure $<3 \mathrm{kPa}$ are also marked in blue.

The run-out areas of powder avalanches with reoccurrence intervals $\mathrm{T}>30$ years and a pressure $<3 \mathrm{kPa}$ are marked in yellow, as well as theoretically not excludable but extremely rare avalanches with a reoccurrence interval $\mathrm{T}>300$ years.

Acknowledgements. The authors thank M. Bründl, Swiss Federal Institute for Snow and Avalanche Research SLF, for continuing support and H. Weck-Hannemann, Institute of Public Finance, University of Innsbruck, for valuable comments on earlier versions of this paper. The authors wish to kindly acknowledge two anonymous reviewers for their suggestions improving the paper.

Edited by: T. Glade

Reviewed by: two referees

\section{References}

Adams, J.: And how much for your grandmother?, Environment and Planning A6, 619-626, 1974.

Adams, J.: The emperor's old clothes: The curious comeback of cost-benefit analysis, Env. Val. 2, 247-260, 1993.

Altwegg, D.: Volkswirtschaftliche Auswirkungen einer Zerstörung alpiner Schutzwälder durch Luftverunreinigungen, Paul Haupt Verlag, Bern, 1988.

Altwegg, D.: Die Folgekosten von Waldschäden. Bewertungsansätze für die volkswirtschaftlichen Auswirkungen bei einer Beeinträchtigung der Schutzwaldfunktion von Gebirgswäldern, Forstwissenschaftliche Beiträge des Fachbereichs Forstökonomie und Forstpolitik der ETH Zürich 8, 1-339, 1989.

Barbolini, M., Natale, L., and Savi, F.: Effects of release conditions uncertainty on avalanche hazard mapping, Nat. Haz. 25, 225244, 2002.

Bateman, I.: Placing money values on the unpriced benefits of forestry, Quart. J. Forestry 86, 152-165, 1992.

Baumann, R., Burkard, A., Wuilloud, C., and Wyer, M.: Paradigmawechsel in der staatlichen Förderung der Naturgefahrenab- wehr. Das Pilotprogramm effor2 im Kanton Wallis, Proc. Internationales Symposion Interpraevent - Villach. 26-30 June 2000, 13-24, 2000.

Bayerisches Landesamt für Wasserwirtschaft: Monetäre Bewertung wasserwirtschaftlicher Maßnahmen - Systematik der volkswirtschaftlichen Nutzenermittlung, Bayerisches Landesamt für Wasserwirtschaft, München, 1981.

BFF and SLF (Swiss Federal Forestry Office and Swiss Federal Institute for Snow and Avalanche Research): Richtlinien zur Berücksichtigung der Lawinengefahr bei raumwirksamen Tätigkeiten, Davos and Bern, Bundesamt für Forstwesen, Eidgenössisches Institut für Schnee- und Lawinenforschung, 1984.

BfS (Swiss Federal Statistical Office): Statistisches Jahrbuch der Schweiz 2002, Verlag NZZ, Zürich, 2002.

Brümmerhoff, D.: Finanzwissenschaft, Verlag Vahlen, München, 1996.

Bundesrat (Federal Council of Switzerland): Entwicklung der Abgaben- und Steuerbelastung in der Schweiz von 1970 bis 2000. Bericht des Bundesrates in Erfüllung des Postulates Vallender vom 14. Dezember 1998, Report 98.3576, Bern, 1998.

Christen, M., Bartelt, P., and Gruber, U.: AVAL-1D: An avalanche dynamics program for the practice, Proceedings Interpraevent 2002 in the Pacific Rim - Matsumoto, 14-18 October, 2002, 715725, 2002a.

Christen, M., Bartelt, P., and Gruber, U.: AVAL-1D, Numerische Berechnung von Fliess- und Staublawinen, Manual zur Software, Eidgenössisches Institut für Schnee- und Lawinenforschung, Davos, 2002b.

Eade, J. and Moran, D.: Spatial economic valuation: Benefits transfer using Geographical Information Systems, J. Env. Man., 48(2), 97-110, 1996.

Frey, R.: Die Nutzen-Kosten-Analyse: Grundzüge, Probleme, Kritik, Wirtschaft und Recht 30, 267-286, 1978.

Fritzsche, A.: Wie sicher leben wir? Risikobeurteilung und -bewältigung in unserer Gesellschaft, Verlag TÜV Rheinland, Köln, 1986.

Fuchs, S. and Bründl, M.: Damage potential and losses resulting from snow avalanches in settlements of the canton of Grisons, Switzerland. Nat. Haz., 34, 53-69, 2005.

Fuchs, S., Bründl, M., and Stötter, J.: Development of avalanche risk between 1950 and 2000 in the municipality of Davos, Switzerland, Nat. Haz. Earth Sys. Sc., 4, 263-275, 2004,

SRef-ID: 1684-9981/nhess/2004-4-263.

Green, C. and Penning-Rowsell, E.: Evaluating the intangible benefits and costs of a flood alleviation proposal, J. of the Institution of Water Engineers and Scientists, 40, 229-248, 1986.

Haering, B., Gsponer, G., and Koch, P.: effor2 - Konzeptbericht. Wirkungsorientierte Subventionspolitik im Rahmen des Waldgesetzes, BUWAL, Bern (Umweltmaterialien 145), 2002.

Heinimann, H., Hollenstein, K., Kienholz, H., Krummenacher, B., and Mani, P.: Methoden zur Analyse und Bewertung von Naturgefahren, BUWAL, Bern (Umweltmaterialien 85), 1998.

Henne, A.: Die Lawinenverbauung Schiahorn-Dorfberg in Davos, Veröffentlichungen über Lawinenverbauungen 1, 1-98, Sekretariat der Eidgenössischen Inspektion für Forstwesen, Jagd und Fischerei, Bern, 1925.

Kahneman, D.: Comments on the contingent valuation method, edited by: Cummings, R., Brookshire, D., and Schulze, W. Valuing environmental goods. An assessment of the contingent valuation method, Rowman and Allanheld, Totowa, 185-194, 1986. 
Keiler, M., Zischg, A., Fuchs, S., Hama, M. and Stötter, J.: Avalanche related damage potential - changes of persons and mobile values since the mid-twentieth century, case study Galtür. Nat. Haz. Earth Sys. Sc., 5, 49-58, 2005.

Laternser, M., Schneebeli, M., and Wüthrich, R.: Die neue SLFSchadenlawinendatenbank, Bündnerwald 51, 35-39, 1998.

Löwenstein, W. : Die monetäre Bewertung der Schutzfunktion des Waldes vor Lawinen und Rutschungen in Hinterstein (Allgäu), edited by: Bergen, V., Löwenstein, W., and Pfister G. Studien zur monetären Bewertung von externen Effekten der Forst- und Holzwirtschaft, Sauerländer, Frankfurt, 117-177, 1995.

Mankiw, N.: Grundzüge der Volkswirtschaftslehre, SchäfferPoeschl, Stuttgart, 2001.

McFadden, D.: Contingent valuation and social choice, Am. J. of Agricultural Econ., 76, 689-708, 1994.

Musgrave, R.: Cost benefit analysis and the theory of public finance, J. of Econ. Literature, 7, 797-806, 1969.

Nash, C., Pearce, D. and Stanley, J.: An evaluation of cost-benefit analysis criteria, Scottish J. of Political Econ., 22, 121-134, 1975.

Nöthiger, C., Elsasser, H., Bründl, M., and Ammann, W.: Indirekte Auswirkungen von Naturgefahren auf den Tourismus - Das Beispiel des Lawinenwinters 1999 in der Schweiz, Geogr. Helv., 2, 91-108, 2002.

Pearce, D.: Valuing risks, edited by: Calow, P.: Handbook of environmental risk assessment and management, Blackwell Science, Malden, 345-375, 1998.
Schulze, W. and Kneese, A.: Risk in benefit-cost analysis, Risk Analysis, 1, 81-88, 1981.

SLF (Swiss Federal Institute for Snow and Avalanche Research): Neue Berechnungsmethoden in der Lawinengefahrenkartierung, Kursunterlagen, Eidgenössisches Institut für Schnee- und Lawinenforschung, Davos, 1999.

SLF (Swiss Federal Institute for Snow and Avalanche Research): Der Lawinenwinter 1999, Eidgenössisches Institut für Schneeund Lawinenforschung, Davos, 2000.

Viscusi, W.: The Value of Risks to Life and Health, J. of Econ. Literature, 31, 1912-1946, 1993.

Wilhelm, C.: Wirtschaftlichkeit im Lawinenschutz. Mitteilungen des Eidgenössischen Instituts für Schnee- und Lawinenforschung 54, Eidgenössisches Institut für Schnee- und Lawinenforschung, Davos, 1997.

Wilhelm, C.: Kosten-Wirksamkeit von Lawinenschutzmassnahmen an Verkehrsachsen, BUWAL, Bern (Vollzug Umwelt, Praxishilfe), 1999a.

Wilhelm, C.: Naturgefahren und Sicherheit der Bevölkerung im Gebirge - oder: von der Schicksalsgemeinschaft zur Risikogesellschaft, Proceedings Forum für Wissen 1999, 2, Nachhaltige Nutzungen im Gebirgsraum - Davos, 27-28 October 1999, 4756, $1999 \mathrm{~b}$.

Worch, B.: Die Anwendung der Kosten-Nutzen-Analyse im Umweltbereich, DDD Druck und Verlag, Darmstadt, 1996. 